404

日本機械学会論文集 ( $\mathrm{C}$ 編)

論文 No. 08-0527

75 巻 750 号 $(2009-2)$

\title{
動力股義足遊脚期制御器の開発と実験評価*
}

\author{
畠 直 輝*1, 久保 勉*2, 井上剛 伸*1 $^{* 1}$
}

\section{Development of a Powered Hip Disarticulation Prosthesis with Swing Phase Controller}

\author{
Naoki HATA*3, Tsutomu KUBO and Takenobu INOUE \\ ${ }^{* 3}$ Research Institute, National Rehabilitation Center for Persons with Disabilities,
} 4-1 Namiki, Tokorozawa-shi, Saitama, 359-8555 Japan

\begin{abstract}
Our proposed powered hip disarticulation prosthesis is a capable to maneuver its hip and knee joint by two geared electric motors. To realize a semi-automatic walking controller depending on a motion of the one's own limb, a swing phase controller, which adjusts the angle of the hip joint at time of foot contact, is implemented in a walking simulation and actual walking experiments. 7th DOF walking simulation, which can move on a sagittal plane, with our proposed method shows a dynamic response that a walking model can walk on a flat floor with varying walking speed as changing the walking speed command. And by a normal subject who wears the prosthesis below his hip with his knee rising on the same side and three users of hip disarticulation prosthesis, walking experiments with varying a swing phase controller's gain for the rotation speed of hip joint of supporting leg has performed on a flat floor. Consequently, completely independent one side robotic lower limb, which has a quite simple swing phase controller, assists the walking successively in normal way.
\end{abstract}

Key Words : Legged Locomotion, Medical and Welfare Assistance, Robot, Biomechanics, Swing Phase Controller

\section{1. はじめに}

動力義足の研究については，国内においても大腿義 足に関する報告(1)などが既にあるが，十分な出力を得 るために油圧を用いるなど重量面での欠点が長く解決 されないでいた。

近年のモー夕技術をはじめ, 演算装置などの軽薄短 小・高性能化，電池技術の向上から，これまでは実現 困難であった義足や歩行補助装具の動力化 ${ }^{(2)}$ が現実 的な段階となってきた。動力化における長所は，より 確実な動作の生成である。受動的な機構では，例えば 躓きや向かい風で遊脚の運動が妨げられた場合，その 運動量を回復すること注難しい。ささらに，装具であれ ば脚力を補助するという効果や歩容矯正といった効果 があげられる、しかしながら，対象者は障害者や運動 能力の低い使用者であるから, 軽量・動作の単純化は 重要な要素となっている。そのため, 自由度を制限し, 駆動力も抑えた仕様でなければならず，步行制御の対 象は自ずと遊脚に向けられることとなる。義足に関

* 原稿受付 2008 年 6 月 10 日.

*1 正員, 国立障害者りハビリデーションセンター(研究所) (䡤359-8555 所沢市並木 4-1).

*2 国立障書者リハビリテーションセンター(研究所).

E-mail : hata@rehab.go.jp
し，遊脚中の制御では鈴木ら $(2004)^{(3)}$ が二重振り子モ デルから遊脚期中の股関節とひざ関節の駆動トルクの 必要性を見出している。遊脚期の制御に必要な役割 は，つま先と床面との間に十分なクリアランスを保ち ながら振り出し，歩行速度を安定に維持又は補償する 着地位置を実現することである，また，歩行速度の変 化に対しての歩数と歩幅の変化に関する研究(4)(5) によ ると健常者の比較的低速な歩行速度 $(5 \sim 6 \mathrm{~km} / \mathrm{h})$ 以内 では歩行速度の変化は歩幅の変化に依存する傾向が強 いことが報告されている，歩幅すなわち着地位置を決 定する手法に関する従来の研究では, Gubina, et al. $(1974)^{(6)}$, Miura, Shimoyama $(1984)^{(7)}$ が, 倒立振り 子の運動方程式を基本として離散的な着地位置切り替 え時点で目標とする歩幅, 歩行速度に収束させる制御 則を提案している. Townsend $(1985)^{(8)}$ は, 前額面で の着地位置に関して解析的な手法により重心運動の摇 動を均一化する指針を示した. Redfern, et al. $(1994)^{(9)}$ は, 定常歩行の際の支持脚の倒れこみ角度と 遊脚の振り出し角度との関係について検証を行い，定 常歩行中は相対的な角度となっていることを見出し た.

本稿では，定常歩行のみならず過渡的な歩容変化に 対応可能な遊脚振り出し制御を提案する。主として義 
足や歩行補助装具への応用を想定し, 支持脚の運動情 報に基づく遊脚振り出し制御を備えたシステムについ て歩行モデルによる数值解析と動力股義足試作機によ る歩行実験により，提案する遊脚振り出し制御の効果 を明らかにする。

\section{2. 歩行モデルの定義}

$2 \cdot 1$ 矢状面ヒト歩行モデル 歩行モデルは 2 次 元平面のみを考光，ヒトを側面から見た方向(矢状面) での運動を扱う．頭部，腕の重量は厳密には考慮せず, 胴体に重心が存在するものとする，床面との接触は脚 先端のみの点接触とし, 脚先端接触点におけるトルク 出力恃光ないものとする，床面から粘弾性特性によ る反力を受けて，床面には極微量沈み込むものとす る.脚構成は, 矢状面上での股関節軸とひざ関節軸を 有する. 図 1 に示す記号配置を参考に, 以下に歩行壬 デルの設定值をまとめる。

$\left|\begin{array}{l|r}\text { mass } m_{1}, m_{2}, m_{3} & 40,5,5 \mathrm{~kg} \\ \text { moment of inertia } I_{1}, I_{2}, I_{3} & 0.8333,0.1042, \\ \text { location of CoG } L_{C} & 0.1042 \mathrm{~kg} \cdot \mathrm{m}^{2} \\ \text { length of link }\left(l_{l}, l_{s}\right) L & 0.25 \mathrm{~m} \\ 0.5 \mathrm{~m}\end{array}\right|$

各パラメー夕值は，実験機重量や実験に協力いただ く被験者らの体重と身長を参考に，構成のシンプルな 数値を用いた。

各仕様は左右脚ともに同様である。したがって，モ デルの総重量は $60 \mathrm{~kg}$ となる。なお, 慣性質量は, 質 点位置を回転中心とした場合のものである。また，取 り扱いの簡素化のため，ふとももとすねの長さは同じ とする，座標系の扱いとして，図2 に示すように破線 で示す植線を基準に CW 方向を正方向として, 股関節 軸角度をぬ，ひざ関節軸角度を $\theta$ とする。胴体は CCW 方向を正方向としてその角度をほとする。ま た, 脚先端から股関節軸までの距離を $D$ とする。そ

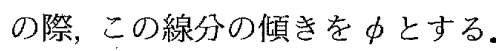

$2 \cdot 2$ 床環境モデル＼cjkstart床面のモデルは粘弾性特性

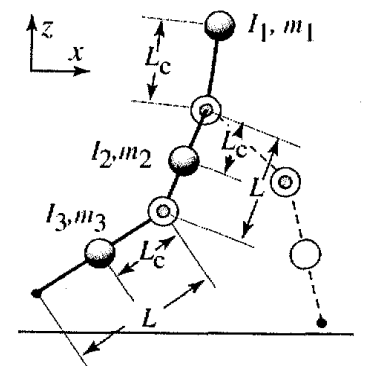

Fig. 1 Sagittal plane stick walking model
で表現し, 垂直抗力 $F_{\text {contact }}$ と水平抗力 $F_{\text {fric }}$ の 2 方向 を持つ反力ベクトルを考える，支持脚部先端の座標を $(x, z)$, 床面高さを $z=0$ とすれば, 以下により算出さ れる。

$$
\begin{aligned}
F_{\text {contact }}= & \max \left(0,-k_{1} \cdot z-k_{2} \cdot \dot{z}\right) \\
F_{\text {fric }}=- & k_{3} \cdot \dot{x} \quad\left(\text { if }\left|F_{\text {fric }}\right| \leq k_{4} \cdot F_{\text {contact }}\right) \\
F_{\text {fric }}=- & \operatorname{sigh}(\dot{x}) \cdot k_{4} \cdot F_{\text {contact }} \\
\quad\left(\text { if }\left|F_{\text {fric }}\right|>k_{4} \cdot F_{\text {contact }}\right) & \ldots \ldots \ldots \ldots . . . . .
\end{aligned}
$$

また, 各パラメータはアスファルトの摩擦係数を参 考に，足先の沈み込みが $1 \mathrm{~mm}$ 程度となるように以下 のように設定した。

$\left|\begin{array}{llr}\text { vertical elasticity } & k_{1} & \\ \text { vertical viscosity } & k_{2} & 400 \mathrm{~N} / \mathrm{mm} \\ \text { lateral viscosity } & k_{3} & 5000 \mathrm{Ns} / \mathrm{m} \\ \text { coefficient of kinetic friction } & k_{4} & 0.8\end{array}\right|$

\section{3. 遊脚振り出し制御モデルの設計}

$3 \cdot 1$ 離散時間振り出し制御 歩行中の $k$ 歩目の 脚切り替气直前の支持脚姿蓺 $\phi$ と角速度 $\dot{\phi}$ を状態変 数 $\boldsymbol{X}[k]$ とする.制御機構を含む倒立振子の離散シス テムは図 3 の制御ブロックとなり, Gubina らの手 法 ${ }^{(6)}$ 参考にすると離散状態方程式は以下の関係と なる。

$$
\begin{aligned}
& \boldsymbol{X}[k+1]=\boldsymbol{A}_{d} \boldsymbol{X}[k]+\boldsymbol{B}_{d} U[k] \\
& \boldsymbol{X}[k]=\left[\begin{array}{c}
\phi[k] \\
\dot{\phi}[k]
\end{array}\right] \ldots \ldots \ldots \ldots \ldots \ldots \ldots \ldots \ldots \ldots
\end{aligned}
$$

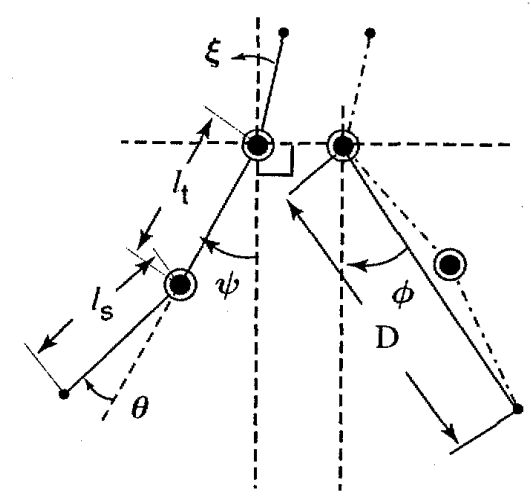

Fig. 2 Nomencalture of lower limbs

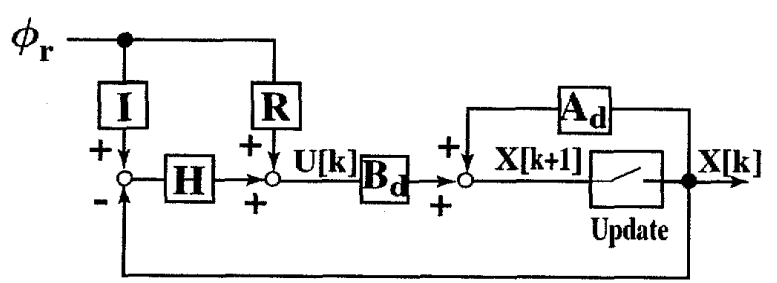

Fig. 3 Walking system with swing leg controller 


$$
\begin{aligned}
\boldsymbol{A}_{d} & =\left[\begin{array}{cc}
\cosh (b T), & \frac{1}{b} \sinh (b T) \\
b \sinh (b T), & \cosh (b T)
\end{array}\right] \\
\boldsymbol{B}_{d} & =\left[\begin{array}{c}
\cosh (b T) \\
b \sinh (b T)
\end{array}\right] \ldots \ldots \ldots \ldots \ldots \ldots \ldots \ldots \ldots
\end{aligned}
$$

ここで, $b=\sqrt{9.8 / z_{h}}$ であり, 重力定数と重心高さ $\left(z_{h}\right)$ によパラメータである。Tは踵接地ごとでみ た半歩周期に要する時間を表わす。さらに，U[k]を 生成する制御部の各項は,

$$
\begin{aligned}
& U[k]=\boldsymbol{H}\left(\boldsymbol{I} \phi_{r}-\boldsymbol{X}[k]\right)+R \phi_{r} \\
& \boldsymbol{I}=\left[\begin{array}{c}
I_{1} \\
I_{2}
\end{array}\right]=\left[\begin{array}{c}
1 \\
\frac{-b \sinh (b T)}{1-\cosh (b T)}
\end{array}\right] \\
& R=-2 \\
& \boldsymbol{H}=\left[h_{1}, h_{2}\right]
\end{aligned}
$$

となる，図中指令值となる $\phi_{r}$ は，支持脚の最終傾き 角度を示すスカラーな目標值である，閉ループを考慮 して式(4)を書き直すと，

$$
\boldsymbol{X}[k+1]=\left(\boldsymbol{A}_{d}-\boldsymbol{B}_{d} \boldsymbol{H}\right) \boldsymbol{X}[k]+\boldsymbol{B}_{d}(\boldsymbol{H} \boldsymbol{I}+R) \phi_{r}
$$

となる。ここまでで明らかなように，H は指令值と 状態変数との差に対するゲイン係数であり，係数決定 に Gubina らは極配置法を用いて以下のように決定し ている.

$$
\boldsymbol{H}=\left[1-z_{1} z_{2}, \frac{\left(1+z_{1} z_{2}\right) \cosh (b T)-z_{1}-z_{2}}{b \sinh (b T)}\right]
$$

ここで， $z_{1}, z_{2}$ は離散システムに打ける極であり， $0 \sim 1$ の範囲をとる。 $z_{1}=z_{2}=0$ とした場合, $\boldsymbol{H}$ はデッ ドビート制御器となり， $\left(\boldsymbol{A}_{d}-\boldsymbol{B}_{d} \boldsymbol{H}\right)^{2}=0$ を実現する. $z_{1}=z_{2}=1$ では指令值の項が消去され, 指令值への追 従が行えなくなる。

本稿では, 特に $z_{1}=0, z_{2} \neq 0$ の場合を扱う。この場 合,

$$
\boldsymbol{H}=\left[1, h_{2}\right]
$$

となり, 式(12)は

$$
\begin{aligned}
& \boldsymbol{X}[k+1]=\boldsymbol{A}_{\alpha}\left[\begin{array}{c}
\phi_{S W}[k] \\
\dot{\phi}[k]
\end{array}\right] \cdots \ldots . . . \\
& \phi_{S W}[k]=-\phi_{r}+h_{2}\left(I_{2} \phi_{r}-\dot{\phi}[k]\right)
\end{aligned}
$$

となる. 理想値での脚切り替え直後の状態 $\boldsymbol{X}_{\mathrm{ini}}=$ $\left[-\phi_{r}, \dot{\phi}_{r}\right]^{T}$ である定常歩行時に, $\boldsymbol{X}_{r}[k+1]=\left[\phi_{r}\right.$ $\left.\dot{\phi}_{r}\right]^{T}=\boldsymbol{A}_{d} \boldsymbol{X}_{\text {ini }}[k]$ が成り立つものとすると,

$$
\dot{\phi}_{r}=I_{2} \phi_{r}
$$

を得る。つまり, 式(16)の右辺第 2 項は歩行速度誤差 をフィードバックする比例制御器となっている，遊脚 の最終的な振り出し角度 $\phi_{S W}$ は, 支持脚の姿勢には無
関係となり，支持脚の倒れこみ角速度 $\dot{\phi}$ と指令值 $\phi_{r}$ から空間座標系の絶対角度として算出可能となる。

$3 \cdot 2$ 下肢の運動制御 本稿で用いる歩行モデル では各軸の最大出力トルクを $400 \mathrm{Nm}$ までとし, 平坦 な床面上を歩行するための運動制御方法を以下のとお りに構成する。

股関節軸の角度制御には，遊脚期と立脚期で目的が 異なるために 2 通りの制御を行う。遊脚期では目標角 度 $\psi_{r}$ に対するPD制御，立脚期では胴体を正立させ るために $\xi$ に対するPD制御を施す。

遊脚期における股関節軸の制御は,

$\tau_{\mathrm{hip}}=1000.0 \cdot\left(\psi_{r}-\psi\right)+100.0 \cdot\left(\dot{\psi}_{r}-\dot{\psi}\right)$

とし，立脚期に扔ける股関節軸の制御は，

$$
\tau_{\text {hip }}=-1500.0 \cdot \xi-60.0 \cdot \dot{\xi} \text {. }
$$

とする。

膝関節軸の角度制御には，遊脚期と立脚期を通して 共通の制御器を用いる.

$$
\tau_{\text {knee }}=400.0 \cdot\left(\theta_{r}-\theta\right)+70.0 \cdot\left(\dot{\theta}_{r}-\dot{\theta}\right)
$$

ただし，床反力の垂直成分が $800 \mathrm{~N}$ を超える場合に は，飛び上りを防止するために次式で表す粘性抵抗の みが㗢くものとする。

$$
\tau_{\text {knee }}=-70.0 \cdot \dot{\theta} \quad\left(\text { if } F_{\text {contact }}>800\right)
$$

次に，軌道の生成方法について説明する。

[遊脚期］足先の運動は，股関節から足首を結ぶ 線分の長さ $D$ に基づいて制御を行う。初期に足部の 引き付けを開始し，終期に足部を振り出す動作には， 三角関数を利用し軌道に追従させる手段を用いる。 $t_{\text {rest }}=T-t$ であり, $0 \leq t \leq T$ の時間経過を表わすも のとして, $D(t)$ は以下の軌道を生成する。

$$
\begin{aligned}
& D(t)=D_{\mathrm{fin}}-0.15 \cdot \sin \left[\pi \cdot\left(1.0-t_{\mathrm{rest}} / T\right)\right] \\
& \quad+\left(D_{\mathrm{ini}}-D_{\mathrm{fin}}(t)-0.06\right) \cdot t_{\mathrm{rest}} / T \cdots \cdots \cdots \cdots
\end{aligned}
$$

ここで, 添え字の ini は足部が離床した時点を意味し, 添え字 fin は，着床する時点を示している， $D_{\mathrm{fin}}$ の算 出は, $t_{\mathrm{rest}}$ 秒後の姿勢推定值 $\phi_{\mathrm{est}}(t)$ を用いて以下の ようになる。

$$
\begin{aligned}
& \phi_{\text {est }}(t)=\phi \cosh \left(b t_{\text {rest }}\right)+\dot{\phi} \sinh \left(b t_{\text {rest }}\right) / b \\
& \ldots \ldots \ldots \ldots \\
& D_{\text {fin }}(t)=\min \left[2 L \cos \left(\phi_{\text {est }}\right) / \cos \left(\phi_{\text {SW }}\right), 2 L\right]
\end{aligned}
$$

$D(t)$ により膝関節軸の動作は次式で決定される.

$$
\theta_{r}(t)=-2.0 \cdot a \cos \left(\frac{D(t)}{2 L}\right)
$$

股関節軸では，振り出し量 $\phi_{S W}$ と $\theta_{r}$ を考慮しなが ら以下のと扔りに決定する。

$$
\psi_{r}(t)=\phi_{S W}+\left(\phi_{\text {ini }}-\phi_{S W}\right) \cdot t_{\text {rest }} / T-\theta_{r}(t) / 2
$$


[立脚期］膝関節軸は伸展方向へトルクを出力 し，睩折れを防止する目的で，過伸展位置の指令值を 設定する。

$$
\theta_{r}(t)=-0.2
$$

なお，本稿での制御の係数や床反力の閾值などの決 定は，試行錯誤的に行った結果のものである.

\section{$3 \cdot 3$ 歩行モデル数值解析 ヒトの歩行を模擬す} るために，矢状面に拝けるヒト歩行モデルを 2 章で定 義した，棒状の脚先端を持つため，足関節は存在せず， 立脚姿勢での重心の直接的な制御は行えないものとす る.つまり，立脚期では着地時の初期状態に応じた惰 性での運動となり，遊脚期のみでの振り出し制御によ る間接的な歩行制御が行われる。

解析を行うにあたり，設定する項目は以下のと扔り である. 歩行モデルの初期状態は, 直立姿勢で静止し た状態とする.

$\left|\begin{array}{l|r}\text { Fixed simulation timing } & 0.005 \mathrm{~ms} \\ \text { Initial states }(\phi, \dot{\phi}) & 0.0,0.0 \\ \text { Pole }\left(z_{1}, z_{2}\right) & 0.0,0.08 \\ \text { Ideal one step time }(T) & 0.5 \mathrm{sec} \\ \text { Ideal value of } z_{h} & 1.0 \mathrm{~m} \\ \text { Gain value of } h_{2} & 0.337 \\ \text { Gain value of } I_{2} & 4.785\end{array}\right|$

遊脚初期における踵の引き付け量や振り出しタイミン
グは，低域の歩行速度に対する相関は低いため，前節 での設定のまま不変とする。

一歩の振り出し時間の目標である目標歩行半周期以 内に遊脚側は振り出しと膝関節の進展を完了するが, 着地の判別・支持脚の切り替光は，遊脚側脚先端に加 わる床反力の垂直抗力 $F_{\text {contact }}>100.0$ の条件で行うも のとする.

指令值 $\phi_{r}$ は解析時刻内において, 股義足での歩行 を想定した歩行速度 $3.5 \mathrm{~km} / \mathrm{h}$ を目標にし, 脚の切り 替わるタイミングに

\begin{tabular}{|c|c|} 
time $t$ & $\phi_{r}$ \\
\hline $0 \sim 8 \mathrm{sec}$ & $0.125 \mathrm{rad}$ \\
$8 \sim 18$ & $\min [0.125+0.05 \cdot(t-8.0), 0.165]$ \\
$18 \sim 30$ & $\min [0.165+0.05 \cdot(t-18.0), 0.19]$
\end{tabular}

のとおりに変化させる.

解析結果から 30 秒後までの結果を図 4 に示す. 図 4 (a) に両下肢の $\phi$ 汇関する結果(歩行中の左右脚 $\phi$ を右側を太線, 左側を鎖線, $\phi_{S W}$ は細線, 指令值 $\phi_{r}$ は 点線)を示す. 図 4(b) には支持脚角速度を示す。指 令值の変化に追従して歩行速度が増加していることが 分かる.図 $4(\mathrm{c})$ には股関節から足先までの線分長さ $D$ の様子を示す. 図 4(d)には床反力の垂直成分 $F_{\text {contact }}$ を示す，両足部とも義足を使用する患者の歩 行時の床反力パターンと類似した 1 峰性となってい

(a)

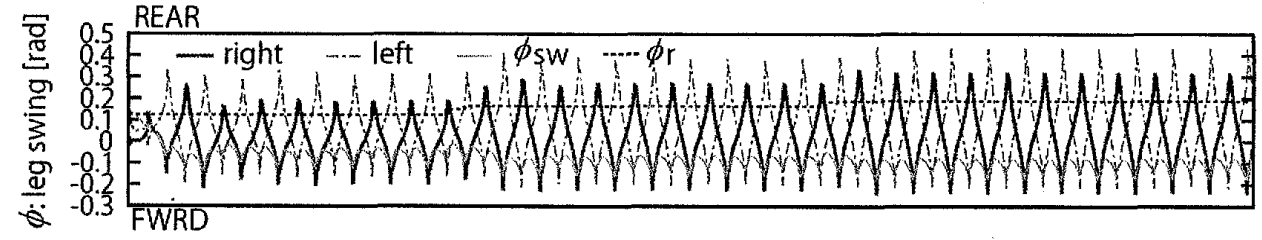

(b)

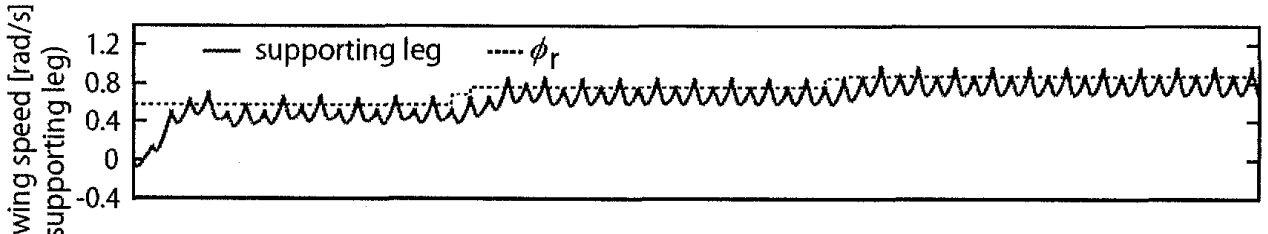

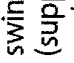

(c)

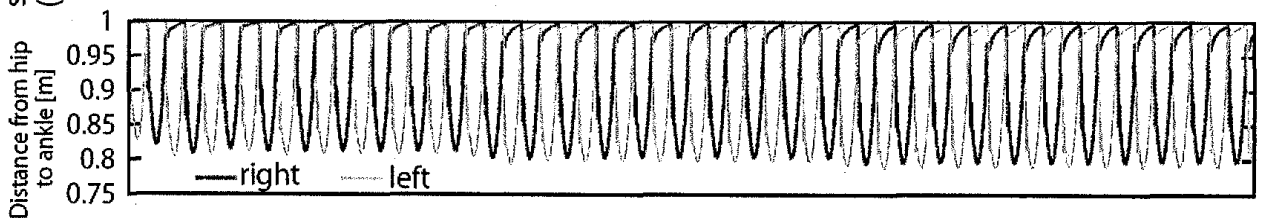

(d)

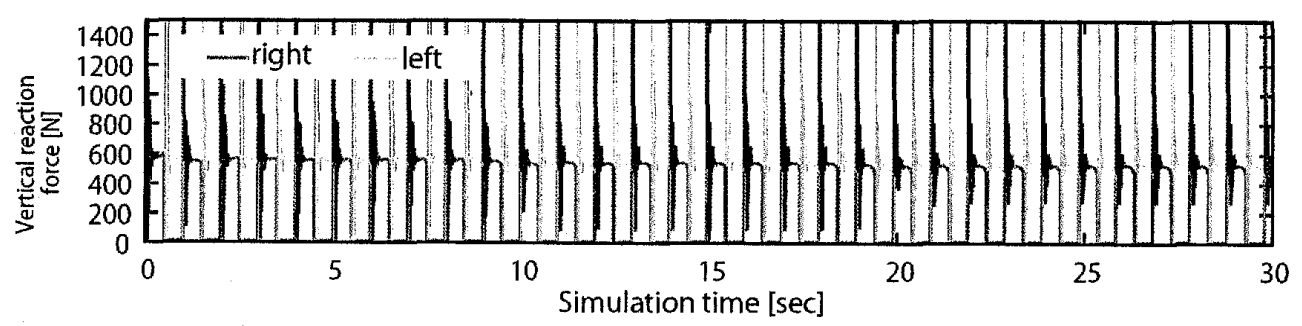

Fig. 4 Sagittal plane walking simulation result 
る. 支持脚先端と床面の接地は粘弾性由来の反力で釣 り合うだけの点接地である. 足部の存在しない自由支 点であり，支持脚による重心運動の制御を用いずにダ イナミックな歩行制御を可能としている。

図 5 に, 本解析による歩行速度 $\overline{\dot{\phi}}$ (支持脚の倒れこ む角速度 $\dot{\phi}$ の 1 歩中の平均) と, 遊脚の振り出し量 $\phi_{S W}$ の関係を示す。図中の結果加ら歩幅の増加に伴 い, 歩行速度が増加していることが分かる. $\phi_{S W}$ と $\bar{\phi}$ の相関関係 $\left(\bar{\phi}=\widehat{I}_{2} \phi_{S W}+o\right)$ を直線による最小二乗近 似で求めると, $\widehat{I}_{2}=5.102$ となり, 式(17)の傾き $I_{2}$ と 比べ, $6.6 \%$ 程度大きい結果となっている.

本解析の歩行周期を図 6 に示吉. 式(24)による $D_{\mathrm{fin}}(t)$ の働きにより, 歩行速度に依らずに目標の歩行 周期 $0.5 \mathrm{sec}$ 実現している。

以上から，式(16)により，反復解析法を用いずに単 純かつ解析的な方法で歩行速度可変と歩行安定化可能 な遊脚振り出し制御の実用可能性が示された。

\section{4. 実験}

前章で提案した，遊脚の振り出し制御を奏際に歩行 を行う股義足に組み入れる試みを行った。

立脚中は安全性に配慮し，実験機股義足のひざ関節 はわずかに過伸展位となるようにモー夕制御し, 機構 的にひざ折れの防止となる姿勢を維持する，遊脚の振 り出し制䘖において歩容を決定する $\phi_{r}$ と $h_{2}$ の設定

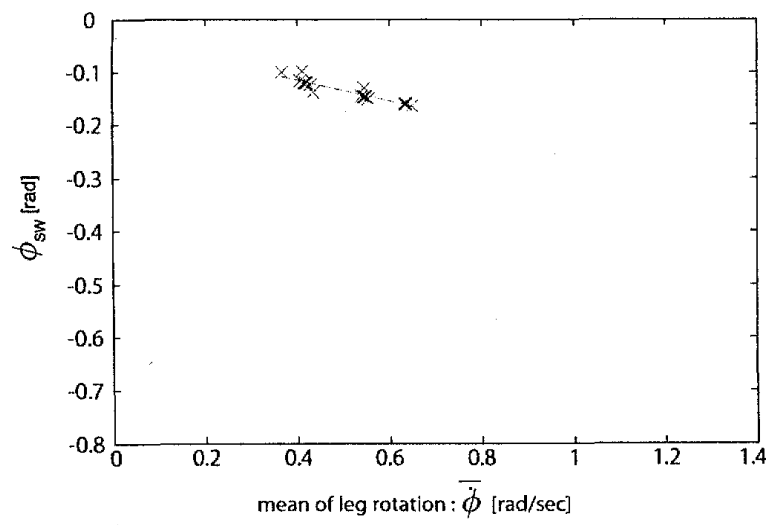

Fig. 5 Simulation result: rotation of supporting leg vs. angle of swing leg

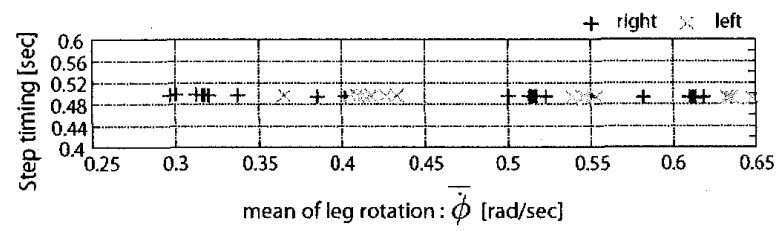

Fig. 6 Simulation result : rotation of supporting leg vs. step timing
のうち, $\phi_{r}$ は固定值 $\phi_{r}=0.35$ とし， $h_{2}$ による歩幅と 歩行速度への影響を調查する。式(16)を変形すると,

$$
\phi_{S W}=\widehat{h}_{2} \cdot \dot{\phi}+C_{\text {coef }}
$$

となることから， $\phi_{r}$ は振り出し量のオフセットとし て働く. 本実験機は腰部を座標の基準としていること から腰部の前弯・後弯方向の姿勢変化により振り出し 量のオフセットを調整可能なこと加ら $\phi_{r}$ の効果を示 すことは難しい，一方で， $h_{2}$ は歩行速度に掛かる係数 であるから, 歩行中の歩行速度の変化から振り出し量 への影響を示すことが可能である。

本実験は遊脚中の実験機の動作を対象とするため, 我々の所属する機関の倫理審查会の承認のもと, 安全 への配慮から予備実験としてはじめに，健常な成人男 性に実験実施の同意を得て実施した。その後，股義足

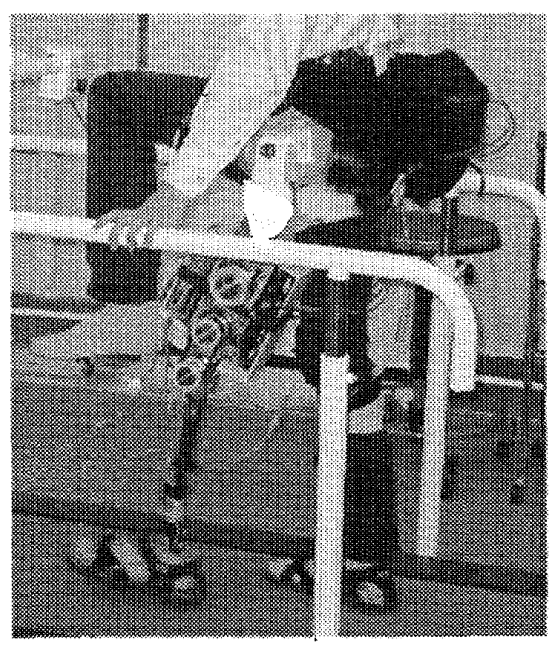

(a)

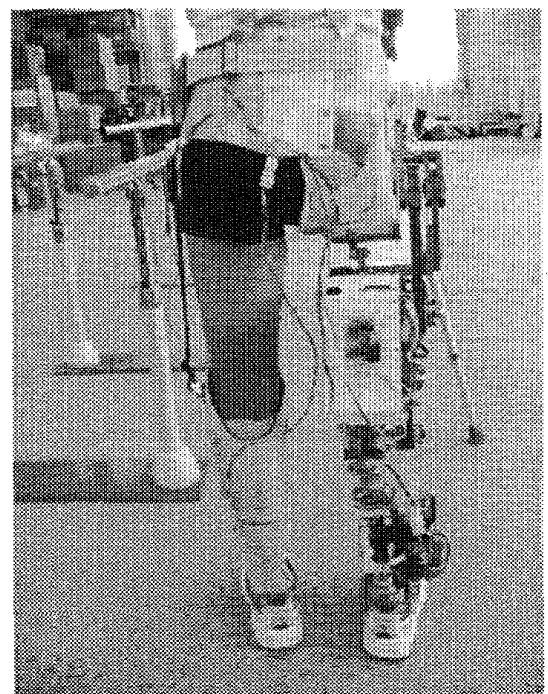

(b)

Fig. 7 Prototype of powered hip disarticulation prosthesis 
使用者による実験は，右側股離断者の3 名に塞験実施 の同意を得て実施した。

[健常者による予備実験］被験者は健常者 1 名 (30 歳, 男性) とし, 歩行を行う両下肢のうち図 7(a) に示すように，右脚を本人の下肢として，左脚を脚式 ロボットとした構成で，遊脚に和ける振り出し動作を 生成する方式について提案手法の制御係数 $h_{2}$ を( 0.1 , $0.2,0.3) の 3$ 段階に変化させて屋内の平坦な床面上 で歩行動作を実施し，制御係数 $h_{2}$ の違いが歩容に与 える影腤を観察する。

［股義足使用者による実験］実験に協力する股義 足使用者 3 名は，右側の股義足を使用して安定した歩 行が可能な運動能力を有している。被験者情報を以下 に示す。

\begin{tabular}{|c|c|c|c|c|} 
Subject & Age & Weight[kg] & Height[m] & Gender \\
\hline I & 43 & 42 & 1.70 & M \\
II & 34 & 50 & 1.73 & M \\
III & 36 & 59 & 1.78 & M
\end{tabular}

使用する制御係数 $h_{2}$ は， $\left(0 \leq h_{2} \leq 0.4\right)$ の範囲で被 験者に躓きや転倒の危険のない範囲に配慮し，制御係 数 $h_{2}$ の違いが歩容に与える影響を観察する。

$4 \cdot 1$ 実験機概要 実験機は，矢状面内で動作す る股関節とひざ関節を有する片脚式ロボットである。 ヒトの下肢の片側と脚式ロボットとの完全に独立させ た状態での一体した歩行動作解析が実施可能となる。 実験機の主要諸元は以下のと扔りである。

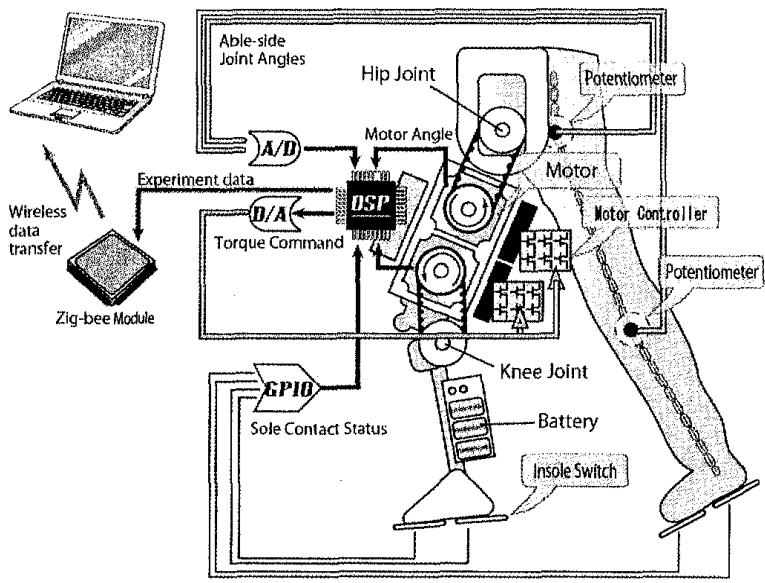

Fig. 8 System diagram

\begin{tabular}{|c|c|}
\hline Architecture & Specification \\
\hline Servo Motor & Max. $30 \mathrm{Nm} / 60 \mathrm{rpm}$ \\
\hline (Torque input type) & $\begin{array}{r}\text { FHA-14 C-100, } \\
\text { HD Systems }\end{array}$ \\
\hline Power Source & $\begin{array}{r}\text { Li-ion type, DC } 25.9 \mathrm{~V} \\
(3.7 \mathrm{Ah})\end{array}$ \\
\hline Processor & $\begin{array}{r}\text { Fixed point } 150 \text { MIPS } \\
\text { eZdsp }\end{array}$ \\
\hline (DSP board) & $\begin{array}{r}\text { F 2812, SpectrumDigital } \\
\text { Inc. }\end{array}$ \\
\hline Angle Sensor & RDC 803001 A, ALPS \\
\hline Insole Switch & CS 105, Bridgestone Corp. \\
\hline Total Weight & $10.2 \mathrm{~kg}$ \\
\hline
\end{tabular}

重心を高め，かつ股関節における負荷慣性モーメン 卜を低隇するために，実験機の大腿部にサーボモー夕 2 基を配し，タイミングベルトを介して股関節とひざ 関節それぞれに動力を伝達する機構とした．機器の構 成イメージを図 8 に示す。大眼部前部にDSP ボード, 後部にモータドライバを配し，下腿にリチウムイオン 電池ケースを固定した。両足の踵・つま先着地を検出 するためのゴムスイッチを内蔵した皮革製中敷きから の ON/OFF のデジタル信号と，七ト側股関節・膝関 節の角度を検出するポテンショメータからのアナログ 信号拉びモータドライバからのモー夕角度信号を DSP ボードへの入力とする.

$4 \cdot 2$ モータ制御 トルク制御方式によるモータ 制御器を用いて P-D 制御を行う。図 9 に P-D 制御器 のブロック図を示す。モータドライバに入力すべき卜 ルク指令情報は, DSP 上で P-D 制御の演算を行い DA コンバータを介して送られる。これにより，少な い計算コストで目標値のステップ状の変化に対して滑 らかな応答を得られ，かつ外部との接触に対してサス ペンション装置のような柔軟性を両立できる。

$4 \cdot 3$ 実験結果実施条件は, 屋内の整った平坦 面を拈々そ $10 \mathrm{~m}$ の距離を直進，折り返して元の位置 八戻る過程を遅い歩行速度と自由な歩行速度の 2 通り とする，健常者での実験では，3 か月間の訓練とシス テム調整を行い安全性を確認した上で実験機の制御係

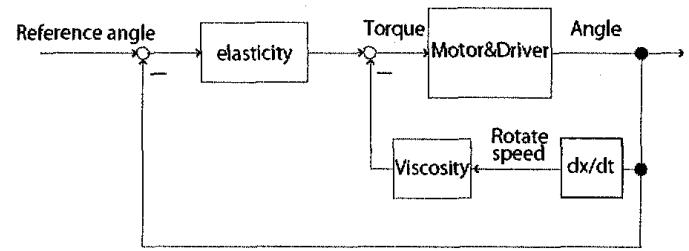

Fig. 9 Diagram of $\mathrm{P}-\mathrm{D}$ Controller 
数 $h_{2}$ を $(0.1,0.2,0.3) の 3$ 段階に替えて合計 6 回を 1 セットとして複数回計測した。股義足使用者での実 験では，実験当日に 2 時間程度の訓練とシステム調整 を行った上で, 被験者 I は $h_{2}$ を $(0.0,0.2,0.4) の 3$ 段階に，被験者 II は $h_{2}$ を $(0.1,0.2,0.3,0.4) の 4$ 段 階に，被験者 III は $h_{2}$ を $(0.0,0.2,0.3,0.4)$ の 4 段階 に替えて遅い歩行と自由な歩行速度について計測し た。

関節角度の初期值は, 直立静止状態での角度が零值 となるようにしている，安全に配慮し，ヒトの下肢で 歩行する側の腕でロフストランド杖または平行棒を使 い，適宜左右方向のバランスを保つようにして転倒防 止を図りつつ実験を行った。

健常者の実験の結果について，図 10 に横軸をヒト
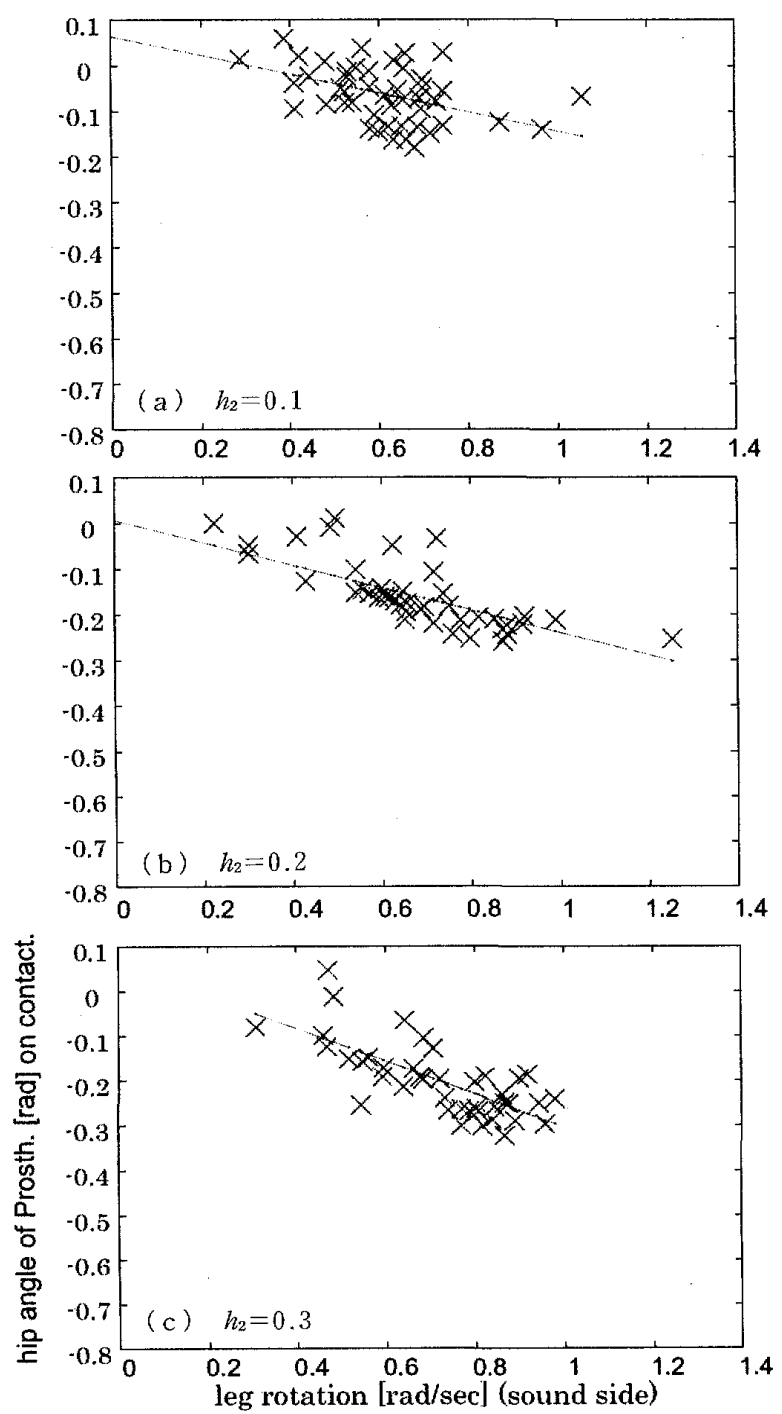

Fig. 10 Foot changing states $\left(\phi_{S W}, \bar{\phi}\right)$ during walking experiments $\left(h_{2}=0.1,0.2,0.3\right)$ by able-bodied subject
脚側支持期中の七ト側股関節角速度平均，縦軸を義足 側着地時の義足側股関節角度で表した。制御係数 $h_{2}$ が図 $10(\mathrm{a})$ では 0.1, 図 $10(\mathrm{~b})$ は 0.2 , 図 $10(\mathrm{c})$ は 0.3 のきの結果である。図中に示す直線は，前章と 同様に直線最小二乗近似を行った結果である，直立時 に比べ歩行中は腰部がわずかに前傾するため，直線の 切片の違いについては言及せずに，直線の傾きに着目 する。

Table 1 Linear relationship between $\bar{\phi}$ and $\phi_{S w}$ by experiments varying $h_{2}$ by able-bodied subject

\begin{tabular}{|c||c|c|c|}
\hline$h_{2}$ & $\hat{h}_{2}$ & $\begin{array}{c}\text { Mean of } \\
\text { residuals norm }\end{array}$ & Samples \\
\hline 0.1 & -0.208 & 0.0085 & 48 \\
\hline 0.2 & -0.246 & 0.0075 & 43 \\
\hline 0.3 & -0.368 & 0.0087 & 41 \\
\hline
\end{tabular}

Table 2 Linear relationship between $\bar{\phi}$ and $\phi_{S W}$ by experiments varying $h_{2}$ by subject I-III

\begin{tabular}{|c|c|c|c|c|}
\hline Subject & $h_{2}$ & $\hat{h}_{2}$ & $\begin{array}{c}\text { Mean of } \\
\text { residuals norm }\end{array}$ & Samples \\
\hline \multirow{4}{*}{ I } & 0.0 & -0.057 & 0.0030 & 21 \\
\cline { 2 - 5 } & 0.2 & -0.066 & 0.0039 & 18 \\
\cline { 2 - 5 } & 0.4 & -0.165 & 0.0038 & 17 \\
\hline \multirow{4}{*}{ II } & 0.1 & -0.119 & 0.0034 & 25 \\
\cline { 2 - 5 } & 0.2 & -0.128 & 0.0097 & 20 \\
\cline { 2 - 5 } & 0.3 & -0.275 & 0.0099 & 25 \\
\cline { 2 - 5 } & 0.4 & -0.370 & 0.0073 & 23 \\
\hline \multirow{4}{*}{ III } & 0.0 & -0.014 & 0.0016 & 20 \\
\cline { 2 - 5 } & 0.2 & -0.238 & 0.0058 & 21 \\
\cline { 2 - 5 } & 0.3 & -0.171 & 0.0052 & 19 \\
\cline { 2 - 5 } & 0.4 & -0.398 & 0.0098 & 12 \\
\hline
\end{tabular}

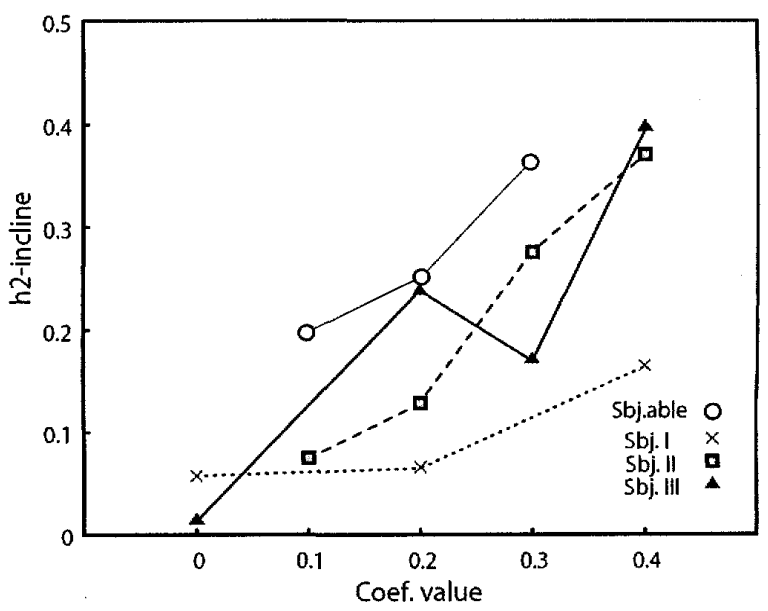

Fig. $11 \bar{h}_{2}$ by Hip disarticulation prosthesis users 
表 1 に図 10 で示した健常者による歩行実験での近 似直線の傾き $\widehat{h_{2}}$ を各制御係数 $h_{2}$ ごとに示す. $h_{2}$ の 増加につれて近似直線の傾きも大きくなる傾向を示し た.

股義足使用者による実験も同様に実施し，その結果 を表 2 に示す．表 1 と表 2 の結果をグラフ化し，図 11 に示す. 設定した $h_{2}$ の増加に伴って $\widehat{h}_{2}$ も大概的に 増加することが確認された。

4・4 実験結果・健常者の歩行比較 実験結果の 比較対象の一般的な歩行データとして, 健常者 6 名に 自由歩行と遅い歩行の 2 通りで屋内平坦面 $10 \mathrm{~m}$ を直 進する歩行を計測した結果を示す。計測にあたって は，両下肢に前述のポテンショメータにより股関節と 膝関節の角度を検出し, 実験機に搭載しているDSP
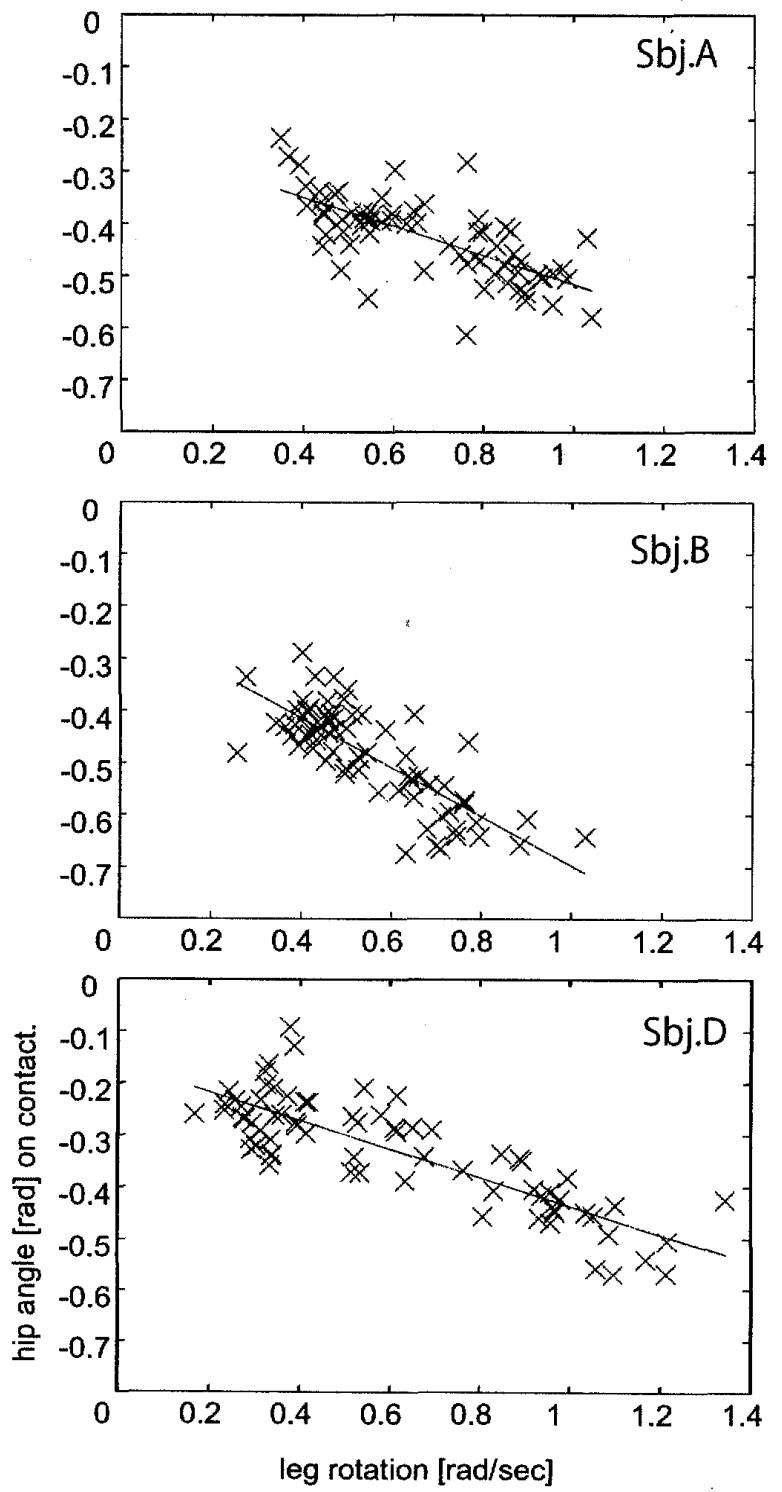

Fig. 12 Foot changing states $\left(\phi_{s w}, \bar{\phi}\right)$ by intact volunteers without walking aids
ボードを使用した。

このうち特にばらつきの少ない被験者 3 名 $(\mathrm{A}, \mathrm{B}$, D) について，前述と同じく，支持期中の股関節角速度 平均値を横軸に，遊脚側が着地する際の股関節角度を 縦軸としたグラフを図 12 に示す。図 12 のプロットを もとに直線による最小二乗近似を行い，その傾きを表 3 にまとめる。これらの結果から，健常なヒトの歩行 では, 歩行速度と遊脚振り出し角度に適度な傾きを有 している場合もあれば，傾きが殆ど水平となる場合も 見受けられる。

\section{5. 考察}

遊脚の振り出し量を制御することによる歩行制御手

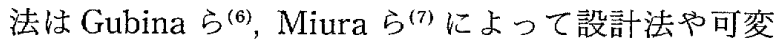
速方法が既に提案されている。本稿では，これらの理 論背景をもとに，股義足への応用を目的とした機構的 な制約のなかでの簡便な扱いを実現するための理論展 開と制御方式を提案した。股義足を動力化することか ら，遊脚の振り出し制御を実装し，歩行速度に対し振 り出し量を $0 \sim 0.4$ 倍の間で調整可能であることを確 認した。線形な歩行モデルによる遊脚振り出し制御の 理論的に歩行安定化可能な範囲 $\left(0 \leq z_{2} \leq 1\right)$ を包含して いる.

制御係数 $h_{2}$ は，小さい值では実験機の大腿部振り 出し量は指令值 $\phi_{r}$ に固定されてしまい, 歩容の変化 に追従しなくなる。逆に $h_{2}$ が大きい場合には過度な 振り出し量を修正するために, 腰を引く動作や着地夕 イミングをずらすなど, 着地後の運動が乱されること となる、つまり，歩行速度に係る係数 $h_{2}$ が適切でな い場合は，本人の意思で制御可能な健側下肢での歩容 調整が行われ, 結果として, 着地周期のばらつきや歩 行速度のばらつきが生じる.表 1,2 の結果から，すべ ての被験者で係数 $h_{2}=0.0$ or 0.1 と $h_{2}=0.3$ or 0.4 の 残差ノルムでは， $h_{2}$ が高い場合に残差ノルムが高くな ることが確認された。しかし，実験に使用した係数 $h_{2}$ で歩容変化に追従しつつ優位に残差ノルムが低下する

Table 3 Linear relationship between $\dot{\phi}$ and $\phi_{S W}$

\begin{tabular}{|c||c|c|c|}
\hline & $\hat{h}_{2}$ & $\begin{array}{c}\text { Mean of } \\
\text { residuals nom }\end{array}$ & Samples \\
\hline Subject A & -0.272 & 0.0067 & 67 \\
\hline Subject B & -0.472 & 0.0070 & 69 \\
\hline Subject C & -0.029 & 0.0078 & 56 \\
\hline Subject D & -0.275 & 0.0070 & 71 \\
\hline Subject E & -0.529 & 0.0110 & 62 \\
\hline Subject F & -0.246 & 0.0141 & 51 \\
\hline
\end{tabular}


特異点を見出すには至っていない。 被験者の動力股義足への習熟度向上を図りつつ, $h_{2}$ による着地周期の変化やエネルギー消費量の比較につ いての調査が我々の今後の課題となる。

また，運動機能に異常のない健常者 6 名の歩行の調 查結果である应 12 と表 3 では, 健常者の支持脚の移 動速度に対する遊脚の振り出しには理論と良好な一致 を示すケースと, 速度に関わらず一様な振り出しとな るケース, 速度に対して歩幅が理論值以上に大きく変 化するケースという想定し得る全ての事象が確認され た.ただし，理論值の範囲内に収まっているケースは， 6 名中 3 名でかつ $\left(-0.28 \leq \hat{h}_{2} \leq-0.24\right)$ という範囲 で, 比較的に局在化している.

理論值から外れるような歩行の場合, 歩行速度の変 化は支持脚での蹴りだしや両脚支持期中の運動制御な どの歩幅以外の動的な制御がより大きく関わっている と考えられる。本稿で提案するような義足・装具のよ うに自由度や出力面で健常な下肢の運動性能に劣るシ ステムでは実現が難しい.

言い換えれば，歩行速度に合わせて歩幅を調整する 機能は自由度や駆動機構の出力が低くても害行可能な コストパフォーマンスに優れた方法であるといえる.

\section{6. 結言}

本稿では義足や歩行補助装具の動力化における歩行 制御の実装について, 動力股義足を試作し, 義足の遊 脚動作に着目して検討を行った。義足や装具はその目 的から軽量であり駆動機構の簡素化が求められてお り，多彩な自由度を配置することは難しい。駆動箇所 を限定し, 出力も抑える場合, 歩行制御は遊脚に重点 が置かれる。そこで，遊脚期での振り出し制御に着目 し，他方の支持脚股関節の矢状面上での角速度から歩 行速度を推定し, 歩容に適した遊脚の振り出しを行う システムを提案した．実験により，動力股義足を健常 者 1 名と右下肢切断者 3 名に装着し, 制御係数による 歩容への影響, 特に歩行速度と遊脚振り出し量の変化 について明らかにした。また，健常な成年男性 6 名の
歩行を計測し，そのうち 3 名が提案する遊脚期制御器 と酷似した特性を有していることを見出した。動力装 具を処方する際，ヒトとの親和性を向上させられるも のと期待できる.

従来股義足を動力股義足に置き換えることのほか, 従来股義足の上に装着する形式の補助動力装具として 健側の下肢動作を反映した補助を股義足へ印加する軽 量で低価格な製品開発へと县げたい.

本研究の一部は文部科学省科学研究費助成金(若手 研究, 課題番号 19700197) を得て実施された。

\section{文献}

(1) Maeda, H., Nishioka, K., Kato, A., Saida, Y., Saeki, Y., Osako, A., Akishita, S., Hagiwara, S. and Tsutani, S., Development of an active artificial leg which enables $\mathrm{a} / \mathrm{k}$ amputees to go up and down stairs, Society of Biomechanisms Japan, Vol. 7 (1984), pp. 178-188.

(2) Kawamoto, H., Lee, S., Kanbe, S. and Sankai, Y., Power Assist Method for HAL-3 using EMG-based Feedback Controller, Proc. of Int. Conf. on Systems, Man and Cybernetics (SMC 2003), (2003-10), pp. 1648-1653.

(3) Suzuki, S., Analytical Study on Control of Above-Knee Prosthesis in Swing Phase, Trans. of the Japan Society of Mechanical Engineering, Series C, Vol. 70, No. 695 (2004), pp. 2110-2117.

(4) Hoshikawa, T., Miyashita, M. and Matsui, H., The relationships between step-length, step-frequency and the speed and/of walking or running, Japan Society of Physical Education, Vol. 16, No.3 (1971), pp. 157-162.

(5) Minami, S. and Ohmichi, H., Step frequency and step length in treadmill walking on the ramp mounts, Japanese Journal of Physical Fitness and Sports Medicine, Vol. 52, No. 2 (2003), p. 222.

(6) Gubina, F., Hemami, H. and McGhee, R. B., On the Dynamic Stability of Biped Locomotion, IEEE Transactions on Biomedical Engineering, Vol. BME-21, No. 2 (1974), pp. 102-108.

(7) Miura, H. and Shimoyama, I., Dynamic Walk of a Biped, The International Journal of Robotics Research, Vol. 3 (1984), pp. 60-74.

(8) Townsend, M. A., Biped Gait Stabilization Via Foot Placement, J. Biomechanics, Vol. 18, No. 1 (1985), pp. 21-38.

(9) Redfern, M. S. and Schumann, T., A Model of Foot Placement During Gait, J. Biomechanics, Vol.27, No. 11 (1994), pp. 1339-1346. 